\title{
Heterotopias of Homelessness: Citizenship on the Margins
}

\author{
Maria Mendel
}

Published online: 2 February 2011

(C) The Author(s) 2011. This article is published with open access at Springerlink.com

\begin{abstract}
The concept of heterotopia challenges political theory, which has often focused on utopic thinking. Foucault describes a heterotopia as a heterogenous space that juxtaposes in a single real place several spaces, several sites that are in themselves incompatible. Streets, squares and parks form heterotopias when their utopic purity as public space is juxtaposed with the private spaces created by the cardboard boxes and other temporary shelters of homeless people. Since citizenship has traditionally been thought of as participation in a democratic public sphere, how do heterotopias of homelessness challenge the ideas about citizenship? Based on narrative research with homeless people in Poland, I show how the homeless conceive of their marginality. Their participation or non-participation in democracy is not hidden but, on the contrary, very visible in public spaces where they are included as excluded.
\end{abstract}

Keywords Homelessness - Heterotopia - Ritual - Democracy · Inclusion as exclusion · Pedagogy of place

\section{Introduction}

In this article, which is based on narrative interviews with homeless people in Gdansk, Poland, I use the notion of 'heterotopia' as a heuristic to rethink homelessness and citizenship. ${ }^{1}$ The organising concept, therefore, is the idea of 'heterotopias of homelessness.'

\footnotetext{
1 The research, inspired by the phenomenological concepts of Norman Denzin (1989) and the autobiographical therapy approach of Duccio Demetrio (2000), was part of a larger project conducted in Gdansk: "The homelessness agenda: The standard of an active return to the labour market". Transcripts of narrative interviews with 31 homeless people provided the data for the analysis. Data collection was conducted by a four-member group from the University of Gdansk and was concluded in the spring of 2006.
}

M. Mendel $(\bowtie)$

University of Gdańsk, Faculty of Social Sciences, Institute of Education,

Ul. Bażyńskiego 4, 80-952 Gdańsk, Poland

e-mail: pedmm@ug.edu.pl 
My understanding of this concept follows Michel Foucault's way of thinking about "other spaces."

There are also, probably in every culture, in every civilisation, real places-places that do exist and that are formed in the very founding of society-which are something like counter-sites, a kind of effectively enacted utopia in which the real sites, all the other real sites that can be found within the culture, are simultaneously represented, contested, and inverted. Places of this kind are outside of all places, even though it may be possible to indicate their location in reality. (Foucault 1984, p. 24)

In the analysis of homeless people's biographical narratives presented below I claim that homelessness is a heterotopia. This is shown through the lens of the notion of the 'Legal world,' the category through which the narrators expressed their lives as simultaneously represented, contested, and inverted. Their citizenship-like their places outside of all places-might therefore be conceived as a citizenship on the margins. One could say, in accordance with Gert Biesta's essay in this issue, that the idea of the 'Legal world' as described by homeless people strengthens the argument against what Biesta refers to as the "domestication of the citizen-a 'pinning down' of citizens to a particular civic identity" (Biesta 2011; this issue). I will come back to these thoughts in the conclusion.

Because the category of the 'Legal world' was formed in a specific context, I will precede the analyses with the following starting thoughts. Their additional purpose is to present the key premises, including the refusal of the existing reality of the 'divided world' and consequently, embedding this work in disagreement-oriented democratic theory.

\section{Ritualisation as "Our" World Order}

According to Foucault (1984, p. 123) heterotopia exists only when traditional time is rejected. Homelessness turns back from "collective" time. It is connected to one's own, very autonomously perceived time, as can be seen in the narratives. This suggests a connection with the idea of the ritual. According to Pierre Bourdieu (1982), ritualisation is a temporal mechanism that enables seizing time by bringing specific occurrences into the ritualisation's space-time continuum. Thus it functions by institutionalising - habit-based, social practices and, as a result, leads to creating institutions. Institutions can be understood as social practices that are built up around a core of ritual and religion (Berger and Luckmann 1966). Religion and its accompanying ritualised actions constitute the pattern and base of institutions. Thus institutions, considered in their original meaning, contain sacred elements. In their essence they are sacred areas, with all their inclusive and exclusive features, magical thinking, etcetera.

Rituals can be seen as a sine qua non condition of our world's existence. Without ritualised social actions, all of what is common, yet diverse (due to the multitude of cultures) and of a constant form, wouldn't exist (see Mendel 2007). At the same time, by creating a vision of social order (though not necessarily in accordance with the existing social order) and postulating its transformation, ritualisation ensures law and order in the world. Furthermore, ritualisation is a process characterised by rites of passage. As the effect of ritualisation, no subject in its individual or social aspect remains the same; they always become different from what they were before the ritual appeared. Rituals thus fulfil a negotiating function and play a role as carriers of social change. 
Because of the fact that without ritualisation everything we have in common-'our' world-would not exist, 'our' world can be seen as an expression of dominance in culture which makes it 'ours' - coherent in a certain form of submission (see Turner 1969). Today, this submission appears to be quite straightforward. 'Our' world is (and is to be, as we can assume in accordance to the everlasting project of its modernisation) institutionalised and rational.

However, due to rituals, which make it magical, despite its rationality, the world is constantly being divided, parcelling out the social space, constantly delineating its margin. Behind this conventional distancing line, a separated world of people 'from the margin'among whom are the homeless - has its place. In a world that is constantly modernised, rituals concerning them are 'rational' processes, carried out within and through the institutions and fit easily in the frame of Arnold van Gennep's (2006) idea of 'rites of passage.' These rituals are a transition from one social status to another, which takes place in three phases: separation, marginalisation and accommodation. In the institutionalised world the transition is a gradual legalisation of the status of a homeless person, which begins with registration procedures and ends with a clear qualification that enables the homeless person to receive benefits. It denominates an unregistered person, a homeless person.

\section{Heterotopias of Homelessness: Places Outside of All Places}

The homeless perceive the world in an ambivalent manner. One could call it a 'dual reality' of the homeless, in which they are part of the common world, but because they are located on its margin, they are also beyond it and they look at it from a distance (and vice versa, so to speak, as the distancing works both ways).

"This isn't my business nor my world," says one of the interviewed (M:50, Al, int.23, p. 180). ${ }^{2}$ His description of the reality he lives in as a homeless person, on an allotment, depicts a sharp opposition of two separate worlds. The contrast between 'us' and 'them' is very striking: "What do you know (...) you don't know about those things” (ibid., p. 178). And what is perceived as completely irrational in one reality, does not surprise within the other: "I'd rather do time, damn..." (ibid.). The rational reality does not seem to react to those 'irrationalities' from outside the margins and manifests its sublime indifference towards the homeless: "but they still won't lock me up" (ibid.).

Hence, the world occupied by a homeless person is not only divided. Its parts remain so separate, that it abstracts and it magnifies the sacred. "This isn't my business nor my world, I'm not God" (M:50, Al, int.23, p. 181). The world that is "not-mine" is so far away, the chance to be addressed by it is so small, that it has to be the world of gods. The distinction between 'us' and 'them', present in all analysed narrations, sometimes includes an explicit accusation. "They took it away from us, I mean, we became homeless, but they can't take away our dignity" (W:52, As, int.11, p. 83), and further: "So that they would treat us like a normal person, not like something...'Cos many times this paper, which lies here, has more value than us, like this normal society (...) 'cos they imagine homelessness somehow different" (ibid., pp. 85-86).

The description of the world with which the homeless do not identify, looking at it from the margin, is a critical vision and an identification of the false conventions and practices

\footnotetext{
2 The interview references are coded as follows: gender (Man or Woman: "M" or "W"), age, category of place in which the interviewee was met (Asylum, Allotments or living "nowhere": "As", "Al" or "N"), number of the interview, and page number.
} 
that characterize it. One of the interviewed strongly stressed the difference between the time before and after the end of the communist regime, which also constituted a point of a radical change in his life. As a result of the political changes in Poland, he became homeless. For him, everything in this 'broken' world is different. As an outsider, he sees the false conventions and practices that are carried out as the 'national care system' with great clarity. Its institutions create fiction.

The job office creates those fictional courses, on which, damn, some additional people make money (...) and as if they were trade workshops, they teach typical jobs there. I've participated in two of those projects and nothing, it gave me nothing, they didn't teach me any profession (...) there's never too few papers in your life, but they didn't teach those people anything. They would clear up on building sites, instead of doing a typically professional job. The money was gone, the settling was done; this is money from the Union, money went down the drain, but it's been ticked off-the job office is doing something (...) The thing is that the state doesn't keep an eye on how this money is spent and how it is treated. It's obvious it's all being wasted. They're all eaten up (ibid., p. 220).

The situation appears similar to other institutions, including those that are meant to solve the problem of homelessness: "SBA ${ }^{3}$ are the most expensive flats, there'll be no homeless person [there]” (M:60, As, int.28, p. 220).

This description is supplemented by ineffective actions of the people at the centre, seen clearly from the respondent's position on the margin, because none of their actions results in a real change expected by people like him. "I respect Mr. S. a great deal and that he comes here during church holidays, says his best wishes, with some priest, then he leaves [but] he only comes and leaves" (ibid., p. 220). From this dual reality, somehow naturally, as a consequence of the constant tension between its two elements, emerges a utopian reality, a project of a better organised world, noticeable in many of the narrations.

Imagine, they live here like a family [in a shelter]. Like a true family. They help each other, they'll share a slice of bread. One has nothing, but helps the other. And you know what? They'll help each other better than those institutions, better than all this shitty social care. Just to give them a free hand, give them a free hand and give them those few cents, so that they can dispose of them TOGETHER [with emphasis]. And they will cope admirably for sure. 'Cos they will find a hut, for four people, say, they'll find accommodation for four people. They will have it like that! 'Cos one will go to work, one will cook, the next one will go to work, the fourth will do the cleaning. And they will always manage. (M:40, N, int.19, p. 148)

The person interviewed brings on the idea of so called squats-widely known among young people, especially those who go abroad to work. They are small communities, which occupy one (usually rented) accommodation. It certainly is a workable solution that enables thinking about finding a way out of homelessness.

Among those 'specific' and workable solutions, there is one that is related with the - not necessarily utopian-idea of cheap housing and service worker brigades consisting of shelter dwellers. "I don't know, they could even do it on the town's outskirts, build very cheap, maybe portacabin flats" (M:60, As, int.28, p. 220) or, for example, care centres as well as shelters for the homeless could convert into repair-construction brigades, offering professional services. The social support services would be mainly arranging the working

\footnotetext{
${ }^{3}$ Social Buildings Association.
} 
conditions and "the shelter would earn, people would have the money, they would get out of homelessness (...) They should create those brigades and people will work cleaning up or weeding gardens, but they don't do it, they don't. (M:60, As, int.28, p. 220). There is no answer to the question why 'they don't do it'. Maybe-as it is stated here- the two parts of the broken world are parties to a conflict: "I want to live a normal life, a 360 degree turn. Maybe we'll meet one day to have coffee, in a year's time. I'll be on the other side of the barricade" (M:37, As, int.17, p. 135).

\section{The Notion of the 'Legal World' in Heterotopias of Homelessness: Real Sites Simultaneously Represented, Contested, and Inverted}

In all interviews it is possible to find references to the dual reality occupied by the homeless. Many of them emphasise 'legality' - a feature of the world that is 'not-mine', 'before the margin', 'broken'. For example, one of the female respondents who was abducted to Germany, where she was sexually abused, reports her escape and detention on the border as follows.

Well, this is what happened, you see, I managed to escape there. And I had no passport, I didn't have my things, I had nothing, I left everything behind. And you see, I waited for twelve hours on the border, before they phoned Poland, to check me up, to see if I'm legal, or, you know...And yes, I managed to escape. (W:28, N, int.1, p. 4)

'Legality' is a distinct feature of rationalised reality that organises itself in institutional forms of social life. Thus, participating in it requires subjecting oneself to countless rituals, performed through procedures and documents that denominate individuals and groups, and that confirm their affiliation and repeatedly define their status, role, position, etcetera. At the same time, the affiliation can be negated by these procedures and documents, and as a consequence, as there are privileged units and groups, some units and groups are also marginalized through particular 'formal' procedures and 'papers', such as certificates, letters of confirmation etcetera.

The strength and foundations of this dominant system are based on economic relations and conditions. Due to its institutions, the 'Legal world' is vested with the system's financial instrumentation and it—ritually—deals out privileges and marginalisation, by distributing the means the entire society is entitled to. Such relations can be seen particularly clearly in narrations about undergoing the procedures and obtaining the documents that are essential in the 'Legal world' and that express a sense of relief or success after having achieved it all.

The so-called 'accomplishment of formalities', characteristic for the ritualised 'Legal world', is a kind of soothing and satisfying fulfilment of a strongly incorporated duty.

Everyone marveled at the fact that I could manage so well, everyone says that I really do great. I won't let myself be led by the nose. 'Cos frankly, Mrs. M or Mrs. B or even (if) you asked me for some document, or something-no problem. I go and I fix it all. I have to. This is my duty, I have to. Right now I'm registered in the job office in W, as I was saying, I'm registered in W. And what? I'm collecting my social benefits and that's it (...) I'm registered and insured. 'Cos I had to have all those certificates, 'cos when you're looking for work $\cdots$ Well, but there's no work so far. (W:47, Al, int.5, p. 39) 
To the homeless, the 'Legal world' reveals itself in activities that make them inclined to perceive it in magical categories, which refer to religious patterns. It is noticeable, among other things:

in the magical 'conditions', which are described by one of the interviewees as follows: "Question: What do you have to fulfill to...live with your son? Answer: Conditions. Question: Mhm... and will you aspire to fulfil the conditions? Answer: I'll try" (W:35, N, int.2, p. 15).

in the grave solemnity and distance that magnify the magical aura of the institutions on which important life issues depend: "The town council is supposed to be a serious council, but people are not really treated seriously there" (W:43, As, int.4, p. 27) and which pass rulings of an existential character (e.g. those concerning having a shelter and every other kind of participation in the 'legal world' involved). A homeless woman who has been making efforts to get a council flat for years, states: "I was getting some letters, especially from the Town Council, so I was surprised that something good was written there. Something bad or good, that I have to report there, that something is moving forward, so maybe I could say some of them were satisfying" (W:43, As, int.4, p. 30).

in the control and supervision used as a consolidation of the homeless' submissive position and carried out in a way, which forces the following magical associations upon a female respondent who illegally occupies a garden shed. "I dreamt of a dog today, so there will be a patrol today, they'll be here soon. Whenever I dream of a dog, they come" (W:49, Al, int.8, p. 62).

in the legitimisation and entitlement of presence by one's appearance; in the constant, requirement for a 'suitable' look, inherent in the institution's organisational culture and in the 'Legal world's' life, often expressed non-verbally. The homeless formulate this requirement in a very suggestive, vivid manner, when they speak of their actions performed in order not to be treated like 'dogs. "I' $m$ trying to prove that I'm not a doormat. I go to the hairdresser once a month, I fix my hair, yes. All my clothes are clean, ironed, I've got everything clean here, yes. How could I visit my mom like that, that's wrong, you know, that's a shame (W:49, As, int.9, p. 67). In the 'Legal world,' like in a temple, one has to be dressed properly, in order not to profane the deity.

in the power to judge, in the unpredictability of judgments and the kindness of the 'Legal world', displayed in an unequal application of rules and occasional departing from them. Like in the world of gods, nobody knows when and what kind of caprice will determine the life of the faithful subjects, yet they can always hope that gods will prove merciful. The rigid demand to pay for traveling by public transport is very burdensome for the respondents and often put forward as an urgent problem to solve. It turns out not to be so rigid for another marginalised group-the disabled. It is as though the 'Legal world' winked to them and kindly allowed for a break in the system and for non-observance of the rule. This is a fragment of a narration of one of the respondents, who introduced himself as "little from birth" and "hydrocephalic": "...before I get here from Wrzeszcz, I have to pay for the bus ticket from Wrzeszcz, and that costs, doesn't it. But those ticket inspectors, they already know me. " $R$ ", isn't it? 'Cos that is " $R$ ", the ones who check the tickets, they all know me by now. And once I showed them the ticket, 'cos I was going to Gdan'sk, (...)—why did you buy a ticket? We know you already, don't we? And he says: I see you with a ticket one more time, and you'll get a fine. And I say: okay (smile). I say: okay, I won't buy 
them anymore. Once I went, that was the last time and there were the same guys, and they say: you have a ticket, don't you? No! I don't have a ticket at all! That's what I said, 'cos I already knew them. Well, then you're lucky, 'cos if you had a ticket, we would fine you" (M:37, As, int.18, p. 137).

Looking at all those elements in the research that describe a rationalised and institutionalised reality, which, due to its religion-based rituals, generate an expelling effect towards the homeless, one notices the specific language of this reality. The first words said by those interviewed, in response to the request to "say something about yourself to start with" express this language in a characteristic manner. The respondents, in order to introduce themselves to the researcher, whom they perceive as a person 'from there', from the 'Legal world', used this world's language, the language in which that world addresses them, 'defining' them through specific qualifications.

I mean, the bad habit I have is that I smoke. I'm not in the high risk group. I mean I don't drink alcohol. I never have. I wasn't dragged to the detoxication ward. And I never disgraced myself with prostitution. That's all I can say about myself. (W:52, N, int.11, p. 79)

Most often those interviewed introduced themselves with a very short 'label': "I've been homeless for 25 years" (M:54, N, int.26, p. 195), or "I'm a non-standard homeless, 'cos I'm an owner of a flat" (M:60, As, int.29, p. 222). They also 'identified' themselves talking about their age, education, 'experience' in homelessness: "I've been homeless for over twenty years (...) elementary education" (W:48, Al, int.7, p. 49), criminal record: "(I did) about thirteen years, last sentence: six" (M:54, Al, int.25, p. 189) and they emphasise their little significance in society: "I'm an ordinary citizen" (M:42, Al, int.20, p. 153).

\section{The Language of 'the Legal World' and Teaching of a 'Good Citizen'}

The people interviewed seem to have learnt these words as a result of multiple contacts with the 'Legal world's' representatives. The institutions, through their personnel, talk to the homeless using a language of surveillance, control, manipulation and supervision, performed (among others) in continuous evaluations, which condition the fulfilment of reporting procedures-peculiarly inflated in Poland. Michel Foucault (1975) calls them repartitioning practices. The 'Legal world' reveals itself to the homeless in the magic of words, in the multiplicity of their condemning repetitions that send them off to the social margin. The magic of words, which, repeated, mark and expel, is a known element of rituals oriented toward social isolation, as described by Pierre Bourdieu and Erving Goffman (see Jacyno 1997, p. 105).

The language of the 'Legal world', following the thought of Basil Bernstein (1975), creates the elaborated code typical for educated people-as opposed to the restricted code used, for example, by the homeless (a code subordinate to the idea of authority and reverence). Possibly, that is why it forms the magic which is spoken about so widely here. And it could also be the reason why the homeless acquire particular phrases or words, which are often repeated to them.

One way or another, the language of institutions and documents generated by them does not build the margin anymore, but a big chasm separating those who, in spite of that, take up the often heroic struggle, virtually breaking through the walls of the 'Legal world.: 
'Cos, for example, when I go to arrange some papers, somebody sends me from door to door, I... It's really hard for me to settle that...I just can't...Then I sit and... cry. It's hard for me to... That really is hard for me. (W:48, As, int.15, p. 114)

The linguistic but also the semiotic codification constitutes a communication barrier.

The inability to understand the codes of the 'Legal world' also strongly reveals itself in the following narration, expressed with fear and danger:

I don't know how this is done, but they wanted to evict me from that house. And I installed an automatic lock there. I'm in contact with the owner of the house, so if they try some other actions, then...so there the matter was dropped, that if they perform some other actions, then he has the address here. Then he is to write me a notice. And, for example, they have subsidies settled and the subsidies are registered out, I don't know how. 'Cos more than once, you know, when I felt down, I wanted to come back home. I don't go to the police, now I've been robbed, I don't have an ID. That was a fresh ID, issued three months ago, the address is written there clearly, isn't it? The exact address. So when they issue it, they will take it to the computer and normally, I have a registration. I come with the police, they have some paper, that I'm registered there. Well, I don't know where to go with this, to find out. (W:49, As, int.9, p. 69)

In light of this and many other narrations it seems that differences in semiotic and linguistic codes create communication barriers that impede the comprehension of relations and procedures necessary for obtaining or maintaining a flat. These barriers may be one of the main factors preventing many people immersed in homelessness from getting out of it. The burdensome, long-lasting 'endeavours' for a council flat during communism and today's neverending attempts to obtain a 'substitute flat,' broadly depicted in the respondent's narrations, can be a description of the difficulties with communication with the 'Legal world.'

According to the narrations, many of which are very similar to the one quoted above, there is no doubt that the rituals of the 'Legal world' form a kind of 'domestication' of the citizen, an attempt to educate them into 'good citizen' (Biesta 2011, this issue) that affects both the privileged and the marginalised.

\section{Everybody Lives Somewhere}

It is obvious that everybody lives somewhere. Even the 'Legal world' presumes that, legally allowing for the lack of address in an ID card, employing some kind of perverse logic, visible in the practice of marking and marginalising the homeless.

On the one-legal-hand, there is freedom to be homeless; on the other-culturalhand there is an expectation and demand that one is not homeless. This can be seen in institutional actions, for example refusing to legalise various 'flats', built or found by the people, who try to cope with accommodation problems (there are regulations, which classify those places as 'uninhabitable places'), thus obstructing self-sufficiency in this field, as such self-sufficiency could threat the housing market and the system of social control. For the homeless, however, especially for those who live in garden sheds, the lack of a legal address is not equivalent with not owning a flat.

I don't know if this is squatting or not, what it looks like. Anyway, I dwell, like in a flat, don't I? (...) Anyway, they hooked up electricity in December and it was so nice 
then (...) I like to have it nice at home. Some adornment, or any other little shit-it must be done, so it brings me joy, no? (W:57, Al, int.12, p. 87)

Their homelessness consists precisely in not having an address, not being able to indicate their legal address. Garden sheds have the status of uninhabitable places and, although the respondents bought and adapted them and-paradoxically - these houses often have an address, with a street name and number, dwelling in them is considered as a case of homelessness in the 'Legal world'.

The perversity of this logic is also based on the lack of acknowledgement that various types of posts, defined as 'shelters', are merely temporary homes for the homeless (similarly to what workers' hostels were in the past) and that a temporary right to use their addresses and one's "place of residence" would facilitate obtaining employment and getting out of homelessness. The homeless sometimes dwell in those places for several years and they are treated like residents, who are responsible for this place, but that proves to be of no legal importance, as the homeless are not considered to "have" an address.

\section{Conclusions}

The main conclusion is presented as a cluster of ideas in which the notion of the 'indispensable redundant' sums up, on the one hand, heterotopias of homelessness, and, on the other, the ambivalent nature of marginality as being outside the centre-outside of all places - but at the very same time also needed by the centre.

The Indispensable Redundant

Stefan Czarnowski (2006) writes about the 'social margin,' defined as people below all the social classes, without a clear social status. From the position of production of material or intellectual goods they are considered unnecessary, so they are considered by themselves (...) unable to find a place in the world (Czarnowski 2006, pp. 95-96). They exist in every society in which the means of production are 'bound'-that is, possessed by an enclosed organisation of producers, a class or a clan; presumably also by the state, with its economic system, and the corresponding work organization-employment, taxes, etcetera.

This very broadly recognised margin consists of the unemployed, homeless, freelancers, criminals, youngsters, still not settled in the reality, and also people culturally not adapted to it. During the 1950's they included former landlords whose properties had been nationalised. Today they may be retired people going through a shock after the regime transformation or people having difficulties with adapting to the world of enterprise. According to Czarnowski, they are seen by society as "insubordinate", as they dare, for example, to "consider that the dinners given out to them are due to them and they expressed dissatisfaction with the poor quality of the distributed groceries" (Czarnowski 2006, p. 96).

Yet, as Czarnowski convincingly shows in his historical review, those people have always existed, generated by the society - a defined group of interest, dominating at the given moment and place, a group usually involved in maintaining the established economical/political system - as a group which is needed by it and conditions its undisturbed existence in the established order. The plebeians were 'utilised' by the urban patriciate to keep the craftsmen 'in check', not allowed to join politically crucial actions, which disciplined the privileged group or limited it in practicing their professions in town. 
Falling out of the group privileged with advantages, they constituted a 'margin', a group of redundant people who were at the same time necessary for the creation and maintenance of institutionalized social practices. Moreover, they were willingly utilised as producers of cheap goods. Thus they were crossing the 'margin' attributed to them, often acting with no accordance to the law, designed, as if, clearly not for them, struggling to survive in existing economic niches. Zygmunt Bauman (2004) describes redundant people along with their not-needed-by-anyone 'life to waste', which is in accordance with Czarnowski's views articulated in 1950s.

\section{Visibility, Domestication and Democracy}

The homeless, who, as is shown in the analysed narrations, always work somehow and somewhere, for example collecting tins and recycling other materials, in today's reality are probably the only ones systematically doing this socially important work. Yet, society shows no sign of recognition for them. Their work is not actually 'work' because it is outside the system, because the homeless are not legally employed and do not pay taxes, and because there is no 'work' for them. The work of the homeless remains collectively unnoticed, although probably every single citizen has seen a homeless person with a trolley filled with iron junk or going through dustbins in search of useful waste.

The social order, with its frameworks in which this work is not considered 'work' and in which neither the work nor the workers are visible, stands on this invisibility. In the light of Rancière's (2007) theory such invisibility might be stopped by spectacular demonstrations (such as performative art) through which people would become visible as valid members of the demos. Thus their visibility would make them accounted as a part of democratic society, being included as excluded.

The invisibility of the work of the homeless is expressed in a number their narrations. They depict a everyday life in which-as is shown in the above analysis-a lot should change, starting with the dominant rationality, disenchanting (to use Weber's term) the social world and making it a 'Legal world', more and more insensitive and inhuman; through legislative changes and legal order, full of paradoxes and explicitly not seized with the idea of social justice, ending with regulations and registration rituals, which consolidate the divisions and intensify the inequalities.

Perhaps, the institutionalised and ritualised life of the 'Legal world' is simply a discursive reality, located in relations of power and-significantly in the context of heterotopias of homelessness-to power (see Szkudlarek 1993). ${ }^{4}$ One could say-in accordance with Biesta's $(2009,2011)$ argument - that it is the milieu of 'domestication' in which the 'good citizen' is formed through rituals and never-ending routines of everyday life subordinated through the political power.

In this context, Zygmunt Bauman (2004) writes about the power founded on fear. Analysing it, Bauman thinks that, in the past, it was a cosmic fear of a great and undefeated power, whereas recently we have to do with official fear, based on law, which was created by, and, at the same time, requires mediation of a human. Both these 'bogies' draw from human defencelessness and uncertainty. The first one is utilised by religious systems, the

\footnotetext{
4 Szkudlarek (1993) develops this idea based on Foucault's thesis about the irreducibility of social life in relations of power, in the context of an analysis of postcolonialism, writing about social strategies not constructed in a 'relation of power' but in a 'relation to power'.
} 
second by political authorities. Constant thinking about the future in the categories of chances and threats in our risk society (Beck 1992) can result from the expanding abilities of acting, with the rising uncertainty of the consequences/results. Referring to human fear, creating adequate conditions for its occurrence is creating the demand for power, justifying its existence. This is not a single action; each political power must systematically renew the foundations of its existence.

According to Bauman, depending on whether the 'waste-people' are generated within a given society or they enter as immigrants, we have to do with either the creation of ghettos or refugee camps. In modern times these asylums gathered the potentially useful individuals in order to bring them back to society. Recently, similarly to prisons, they are merely waste storages, carefully guarded and supervised, so the "toxic fumes" do not filter into the healthy social tissue (Bauman 2004, p. 94). It seems to be caring for the safety of the 'sane', yet their actions are dictated by fear-they can join the ones rejected by society themselves. This way, power evoking fear is legitimised by the socially created strategies of managing it. Waste-people lose the ability to assimilate. Here we can see a ritualised transition from recycling waste-people to disposing of them through isolation and oppression, superficially justified by socio-economic factors. Bauman calls it "sealing the container" (ibid., p. 134).

Is democracy possible in such reality? Perhaps Rancière's ideas on how to make people visible and accounted with their democratically valid voice will let us say yes.

\section{Challenges}

However these issues are interpreted in educational work, it seems most important to reformulate the social role of redundant people and, seeing the heterotopia of homelessness, to cease obscuring their indispensability. It also seems crucial to guard against totalising forms of acting.

First of all it seems worthwhile to underline that the homeless people in their narratives see themselves through the eyes of the 'Legal world'. It is easy to notice that they already have an idea of what a good citizen is, and they very much want to 'qualify' to be that kind of citizen. Therefore, it might be a significant challenge to make an educational inception of the idea of the 'ignorant citizen' (Biesta 2011) in social life, in its rituals and everyday routines. Not 'upbringing' or 'schooling,' but distanced educational work with autonomous subjects, for their agency and subjectivity. As Biesta argues:

(T)he democratic citizen is not a pre-defined identity that can simply be taught and learned, but emerges again and again in new ways from engagement with the experiment of democratic politics. The ignorant citizen is the one who is ignorant of a particular definition of what he or she is supposed to be as a 'good citizen.' (Biesta 2011, this issue)

According to Zygmunt Bauman (2004), when we start designing the forms of human coexistence, human beings become waste. Therefore all the forms of 'designed' education must be forgotten.

Considering this, we should replace the old discourse with a new one, using Rancière's and Biesta's idea of 'ignorance.' It probably does not include a change of beneficiariesthey will remain corporations, countries and other organisations binding the sources of resources, providing access to the changing goods-but heterotopias such as homelessness can alter significantly. 
Yet, every human action is only partly predictable; every institution, even the most total one, leaves space for negotiating roles to be played and maintaining the total order (see Laclau 1996). As Rancière (1999) argues, disagreement is a direct confrontation with the shares of sensible reality which make visible the invisible governments (mostly the government of the financial institutions). The 'visualisation,' whose need is expressed here in relation to the described heterotopia of homelessness, may be started by a chain of unpredictable disagreements. It could become, for instance, systemic educational and cultural actions based on creating critical distance towards ritualisation and planned, systematic work towards changing the rituals. As I have mentioned, in the institutionalised world and because of its focus on the homeless, the ritual transition is a gradual legalisation of the status of a homeless person. Heterotopias of homelessness described on the basis of my study represent, contest and invert these practices. They are educationally meaningful by showing the 'other places' for inclusion and for citizenship, not on the margins. One could see this as an appeal for re-ritualisation and re-domestication of the world in which we act, its critical rethinking and re-practicing in the light of Rancière's (2007) conception of the division of the sensible. This chain could initiate emergence of different kinds of social self-organisation that could lead to deeper changes in ourselves, our being-in-the-world, to social and cultural change. Therefore, in accordance with what Freire (2000) taught, there is a need to improve and to develop the educational work towards freedom as cultural action.

But while considering the discourse of freedom (negotiating between education and identity) we can easily notice that the process of changing reality demands more than social narratives (see also Szkudlarek 1993). The social dramas seem to be lying in the centre of educational work towards social and cultural change, which I strive for in the light of my heterotopias study. As Szkudlarek states:

Reality, with its dimensions of practical life, cannot be fully narratized, even though its narratization is a prior aim of discursive practices... [W] ithin the discursive sphere the practical plays the role of undecidable, of a 'third' dimension of all conceptual dualisms. This aspect of the practical has been realized in the philosophy of language even before deconstructionism. ( $\cdots$ ) Knowing the practical is, therefore, a particular act of cognition, different from 'specifically human' conceptual dualism. It is no wonder, then, that in the discursive struggle, inevitably stretching itself between polarized dichotomies, the sphere of practical knowing can play a deconstructive, liberating role and provide for a standing from which to interrogate all ideological positions. (Szkudlarek 1993, pp. 137-138)

He identifies it as a pragmatic trace of emancipatory thinking (ibid., p. 138). Perhaps such a trace runs through the social dramas in which people might consciously change their everyday routines and reverse those rituals that ruin the sensible world. Therefore there is also a need for education towards conscious social playing, changing the rituals organizing and maintaining the hegemonic type of social order. This education may be fruitfully rooted in the anthropological achievement of Victor Turner (1975) and theory of social theatre developed by Augusto Boal (1992). Educational thought and practice based on such roots and keeping the already mentioned orientation could be productive in a process of $r e$ ritualisation, as educated social practice. It seems to contribute-following Jacques Rancière-to the formation of collective speakers who throw into question the distribution of roles, of territories, of languages - on short, political subjects who upset an established sharing and division of the sensible (as cited in Holmes 2001, p. 64). It sounds explicitly as 
educational challenge and this is one of the most challenging dimensions of a 'pedagogy of place' (Mendel 2006). ${ }^{5}$

These reflections are not meant to be a call for a 'new pedagogy'. It is, most of all, the question of developing forms of educational action that aim at building critical distance towards ritualised social practices that organise the space of 'our-ness,' of which we are both producers and products.

Acknowledgments I would like to express my gratitude to the anonymous reviewer and to Claudia Ruitenberg for their inspiring comments that helped me to prepare the final version of the paper.

Open Access This article is distributed under the terms of the Creative Commons Attribution Noncommercial License which permits any noncommercial use, distribution, and reproduction in any medium, provided the original author(s) and source are credited.

\section{References}

Bauman, Z. (2004). Zycie na przemiat [Wasted lives: Modernity and its outcasts]. Kraków: Wydawnictwo Literackie.

Beck, U. (1992). Risk society. Towards a new modernity. New Delhi: Sage Publications.

Berger, P. L., \& Luckmann, T. (1966). The social construction of reality: A treatise in the sociology of knowledge. Garden City, NY: Anchor Books.

Bernstein, B. (1975). Towards a theory of educational transmissions. London: Routledge \& Kegan Paul.

Biesta, G. J. J. (2009). Sporadic democracy: Education, democracy and the question of inclusion. In M. Katz, S. Verducci, \& G. Biesta (Eds.), Education, democracy and the moral life (pp. 101-112). Dordrecht/Boston: Springer.

Biesta, G. J. J. (2011). The ignorant citizen: Mouffe, Rancière, and the subject of democratic education. Studies in philosophy and education (this issue).

Boal, A. (1992). Games for actors and non-actors. London: Routledge.

Bourdieu, P. (1982). Les rites comme actes d'institution. Actes de la Recherche en Sciences Sociales, 42, 58-63.

Czarnowski, S. (2006 [1956]). Ludzie zbedni w sluzbie przemocy [The redundant people serving for violence]. Miscellanea Anthropologica et Sociologica VII, Special issue: Bezdomnosc [Homelessness], 95-105.

Demetrio, D. (2000 [1995]). Autobiografia. Terapeutyczny wymiar pisania o sobie [Raccontarsi. L'autobiografia come cura di sé] (A. Skolimowska, Trans.). Kraków: Impuls.

Denzin, N. (1989). Interpretive biography. London: Sage.

Foucault, M. (1975). Discipline and punish: The birth of the prison. New York: Random House.

Foucault, M. (1984). Of other spaces (1967), Heterotopias (J. Miskowiec, Trans.). Architecture/Mouvement/ Continuité. http://www.foucault.info/documents/heteroTopia/foucault.heteroTopia.en.html.

Freire, P. (2000). Cultural action for freedom (Revised ed.). Monograph Series No. 1. Cambridge, MA: Harvard Educational Review.

Holmes, B. (2001). Hieroglyphs of the future: Jacques Rancière and the aesthetics of equality. Cabinet Magazine, 4. http://www.cabinetmagazine.org/issues/4/Hieroglyphs.php.

Jacyno, M. (1997). Kontrkultura ubóstwa. Pierre'a Bourdieu koncepcja reprodukcji klas spolecznych a problem reprodukcji otwartej [The counterculture of poverty. Pierre Bourdieu's conception of social class reproduction and problem of open reproduction]. Studia Socjologiczne, 3(146), 101-120.

Laclau, E. (1996). Emancipation(s). London: Verso.

Mendel, M. (Ed.). (2006). Pedagogika miejsca [Pedagogy of place]. Wroclaw: Wydawnictwo DSW.

\footnotetext{
5 I have developed the idea of a 'pedagogy of place' as a field of research and educational practice in which reflection on anthropological, social and physical space grounds all their dimensions. This conception composes itself in the context of the spatial turn (see, for example, the work of Doreen Massey, Edward Soja, Michel de Certeau, Yi-Fu Tuan, and others). The phenomenological perception of human beings through the lens of space redefines crucial pedagogical concepts and changes the meaning and the role of education. The Heideggerian unity of subject and place in the pedagogy of place works as an assumption of continuing space-awareness in education.
} 
Mendel, M. (2007). Spoleczenstwo i rytual. Heterotopia bezdomności [Society and ritual: Heterotopia of homelessness]. Torun: Adam Marszalek.

Rancière, J. (1999 [1995]). Disagreement: Politics and philosophy (J. Rose, Trans.). Minneapolis: University of Minnesota Press.

Rancière, J. (2007 [2000]). Dzielenie postrzegalnego. Estetyka i polityka [Le partage du sensible: Esthetique et politique] (J. Sowa, Trans.). Kraków: Korporacja Ha!art.

Szkudlarek, T. (1993). The problem of freedom in postmodern education. Westport, CT: Bergin \& Garvey. Turner, V. (1969). The ritual process: Structure and anti-structure. Chicago: Aldine Publishing.

Turner, V. (1975). Dramas, fields, and metaphors: Symbolic action in human society. Ithaca, NY: Cornell University Press.

Van Gennep, A. (2006 [1909]). Obrzedy przejscia [Les rites de passage] (B. Bialy, Trans.). Warsaw: PIW. 